\title{
FINANCIAL RATIO AND ITS INFLUENCE TO PROFITABILITY IN ISLAMIC BANKS
}

\author{
Erika Amelia ${ }^{1}$
}

\begin{abstract}
Financial Ratio and Its Influence to Profitability in Islamic Banks. This research aims to analyze the influence of the Capital Adequacy Ratio (CAR), Non Performing Financing (NPF), Financing to Deposit Ratio (FDR) and Biaya Operasional Pendapatan Operasional (BOPO) to Return on Asset (ROA) in Bank Muamalat Indonesia and Bank Syariah Mega. The data analysis method used in this research is multiple regression analysis. From the test results show that the Capital Adequacy Ratio (CAR), Non Performing Financing (NPF), Financing to Deposit Ratio (FDR) and Biaya Operasional Pendapatan Operasional (BOPO) simultaneously effect to Return on Asset (ROA). Based on the test results of the $t$ statistic was concluded that the Capital Adequacy Ratio (CAR), Non Performing Financing (NPF) and the Financing to Deposit Ratio (FDR) partially no significant effect to Return on Asset (ROA), while Biaya Operasional Pendapatan Operasional (BOPO) partially significant effect to Return on Asset (ROA).
\end{abstract}

Keywords: financial ratio, profitability, Islamic banks, multiple regression

Abstrak: Rasio Keuangan dan Pengarubnya Terbadap Profitabilitas di Perbankan Syariah. Penelitian ini bertujuan untuk menganalisis pengaruh Capital Adequacy Ratio (CAR), Non Performing Financing (NPF), Financing to Deposit Ratio (FDR) dan Biaya Operasional Pendapatan Operasional (BOPO) terhadap Return on Asset (ROA) pada Bank Muamalat Indonesia dan Bank Syariah Mega. Metode analisis data yang digunakan dalam penelitian ini adalah analisis regresi berganda. Dari hasil uji statistik F menunjukkan bahwa Capital Adequacy Ratio (CAR), Non Performing Financing (NPF), Financing to Deposit Ratio (FDR) dan Biaya Operasional Pendapatan Operasional (BOPO) secara simultan berpengaruh terhadap Return On Asset (ROA). Berdasarkan hasil uji statistik t disimpulkan bahwa Capital Adequacy Ratio (CAR), Non Performing Financing (NPF) dan Financing to Deposit Ratio (FDR) secara parsial tidak berpengaruh signifikan terhadap Return On Asset (ROA) sedangkan Biaya Operasional Pendapatan Operasional (BOPO) secara parsial berpengaruh signifikan terhadap Return On Asset (ROA).

Kata Kunci: rasio keuangan profitabilitas, bank syariah, regresi berganda

First draft: January, $15^{\text {th }}$ 2015, Revision: March, 10 ${ }^{\text {th }} 2015$, Accepted: April, $20^{\text {th }} 2015$

${ }^{1}$ Syarif Hidayatullah State Islamic University. Jl. Ir. H. Juanda No. 95, Ciputat, South Tangerang, Banten, Indonesia.

Email: erika.amelia@uinjkt.ac.id 


\section{Introduction}

Crises that have occurred in the Indonesian banking industry has been aware of all parties that the conventional banking system is not the only system that is reliable, but there is another banking system better is Islamic banking. In the banking activities, the implementation of Islamic teachings are realized by the implementation of sharia banking activity that is consistent with Islamic thought on economic activity. Along with the increasing economic growth, Islamic finance has also increased (Santoso and Sigit Triandaru, 2006)

In order to maintain public confidence, the banks must maintain financial performance. The bank's financial performance can be assessed by several indicators. One of the main indicators used as the basis of assessment is the bank 's financial statements. Based on the financial statements will be calculated a number of financial ratios commonly used as the basis of assessment of the bank (Riyadi , 2006). Recognizing the importance of health of a bank for the establishment of confidence in the banking world as well as to implement the precautionary principle (prudential banking) in the banking sector, Bank Indonesia felt the need to apply the rules on the health of banks. With the bank 's health regulations, banks are expected to always be in good health, so it will not harm associated with the banking community (Santoso and Sigit Triandaru , 2006)

To know the financial condition of a bank, it can be seen that the financial statements are presented by a bank periodically. This report is very useful, especially for owners, management, government, and society as a bank customer, in order to determine the condition of the bank (Kasmir,2012). Bank rating include an assessment of the factors which consists of: Capital; Asset Quality; Management; Earnings; Liquidity; Sensitivity to Market Risk.

In this study, aspects of capital assessed through the Capital Adequacy Ratio (CAR), asset quality aspects assessed through Non Performing Financing (NPF), the aspect of profitability assessed by return on assets (ROA) and Operating Expenses to Operating Income (ROA), while the liquidity aspect assessed through Financing to Deposit Ratio (FDR).

Some research show different results, the not the consistency of the results of research has been done before, and then the researcher are interested in similar research regarding, "The Effect of Capital Adequacy Ratio (CAR), Non Performing Financing ( NPF ), Financing to Deposit Ratio ( FDR ) and Operating Expenses Operating Income ( OEOI) to return on Assets ( ROA) in Bank Muamalat Indonesia and Bank Syariah Mega registered in Bank Indonesia period 2005-2012” 


\section{Literature Review}

The bank's financial statements show the financial condition of the bank as a whole. From this report will be read how the actual condition of the bank, including the weaknesses and strengths (Kasmir, 2012). The purpose of making the bank's financial statements with the principles of Islamic Sharia is (Rifqi Muhammad, 2008): first, improving obedience to the principles of Islamic transactions in all transactions and business activities; Second, information sharia compliance by the entity on Islamic principles, as well as information assets, liabilities, and expenses opinion incompatible with Islamic principles if there is and how the acquisition and use; Third, information to help evaluate fulfillment of responsibilities sharia entity to trust in securing funds and invest in a decent profit levels; Fourth, information about the level of investment profits earned investors and owners of temporary syirkah funds and information regarding the fulfillment of the obligation (obligation) social function sharia entities, including the management and distribution of zakat, infaq, shodaqoh and wakaf.

The health of banks is the result of qualitative assessments of various aspects affecting the condition or performance of a bank through the assessment of financial, asset quality, management, earnings, liquidity and sensitivity to the market risk (Santoso and Sigit Triandaru, 2006). The rules about the health of Islamic banks have been set by Bank Indonesia Regulation (PBI) No. 9/1 / PBI / 2007 concerning the Rating System for General Banks Based on Sharia Principles (in http://www.bi.go. id, downloaded on September 6, 2013) subject and according to Bank Indonesia Circular Letter No. 9/24 / DPbS October 30, 2007 regarding the rating system for commercial banks based on Islamic principles (in http://www.bi.go.id, downloaded on 8 September 2013).

The bank rating of health banks include an assessment of the following factors: First, an assessment of the capital factor includes assessment of the following components: adequacy, projected (future trend) capital and the ability of capital to cover risks; and; The ability to meet the need for additional capital from earnings, capital plan to support business growth, access to sources of capital and financial performance of shareholders.

Second, an assessment of the asset quality factor includes assessment of the following components: The quality of productive assets, the development of the quality of earning assets, concentrations of risk exposure, and risk exposure core customers; The adequacy of policies and procedures, review systems (review) internal, system of documentation and handling performance earning assets.

Third, an assessment of the management factors include assessment of the 
following components: The quality of general management, application of risk management, primarily on the understanding management on the risk of Bank or UUS; Obedience of Bank or UUS on applicable provisions, a commitment to Bank Indonesia or other parties, and adherence to Islamic principles, including educating the public execution of a social function.

Fourth, an assessment of the earnings factor includes assessment of the following components: Ability to produce profits, earnings capacity to support the expansion and risk cover, as well as the level of efficiency; Diversification of revenue, including the ability of banks to earn fee-based income, and diversification of investment of funds, and also application of accounting principles in the recognition of income and expenses

Fifth, an assessment of the liquidity factors include assessment of the following components: the ability to fulfill short-term obligations, the potential maturity mismatch, and the concentration of funding sources; the adequacy of liquidity management policies, access to funding sources, and funding stability.

Sixth, assessment of sensitivity to market risk factors include assessment of the following components: the ability of the Bank or Sharia capital covering potential losses as a result of fluctuations (adverse movement) exchange rates; the adequacy of the implementation of market risk management. Return on Assets (ROA) is used to measure the bank's management in the gain (profit) as a whole. The greater Return On Asset (ROA) of a bank, the higher the level of the bank's profits achieved and the better the bank's position in terms of the use of the asset (Dendawijaya, 2009).

Table. 1

\begin{tabular}{ccc}
\multicolumn{3}{c}{ Criteria of Return On Asset (ROA) Level Assessment } \\
\hline Level & Criteria & Information \\
\hline Level 1 & ROA $>1,5 \%$ & Very high \\
Level 2 & $1,25 \%<$ ROA $\leq 1,5 \%$ & High \\
Level 3 & $0,5 \%<$ ROA $\leq 1,25 \%$ & High Enough \\
Level 4 & $0 \%<$ ROA $\leq 0,5 \%$ & Low \\
Level 5 & ROA $\leq 0 \%$ & Very low \\
\hline
\end{tabular}

Source: Bank Indonesia Circular Letter No. 9/24 / DPbS 2007

Capital Adequacy Ratio (CAR) is called with the capital adequacy ratio, which means that the amount of equity capital required to cover the risk of financial loss that may arise from cultivation of assets are risky. The greater this ratio, the bank's profit will also increase. In other words, the smaller the risk of a bank, the greater profits of a bank (Kuncoro and Suhardjono, 2011). 
Table. 2

Criteria of Capital Adequacy Ratio (CAR) Level Assessment

\begin{tabular}{ccl}
\hline Level & Criteria & \multicolumn{1}{c}{ Information } \\
\hline Level 1 & KPMM $\geq 12 \%$ & Significantly higher than certainty \\
Level 2 & $9 \% \leq \mathrm{KPMM}<12 \%$ & higher than certainty \\
Level 3 & $8 \% \leq \mathrm{KPMM}<9 \%$ & Less higher than certainty \\
Level 4 & $6 \%<\mathrm{KPMM}<8 \%$ & Lower than certainty \\
Level 5 & $\mathrm{KPMM} \leq 6 \%$ & Less lower than certainty \\
\hline
\end{tabular}

Source: Bank Indonesia Circular Letter No. 9/24 / DPbS 2007

Non-Performing Financing (NPF) is used to measure the level of financing problems faced by Islamic banks. The higher this ratio, indicating the quality of Islamic bank financing is getting worse (Mohammed, 2005).

Table. 3

Criteria of Non Performing Financing (NPF) Level Assessment

\begin{tabular}{ccc}
\hline Level & Criteria & Information \\
\hline Level 1 & $\mathrm{NPF}<2 \%$ & Very good \\
Level 2 & $2 \% \leq \mathrm{NPF}<5 \%$ & Good \\
Level 3 & $5 \% \leq \mathrm{NPF}<8 \%$ & Good Enough \\
Level 4 & $8 \% \leq \mathrm{NPF}<12 \%$ & Less good \\
Level 5 & $\mathrm{NPF} \geq 12 \%$ & Not good \\
\hline
\end{tabular}

Source: Bank Indonesia Circular Letter No. 9/24 / DPbS 2007.

Financing to Deposit Ratio (FDR) is how much third party funds be released for financing Islamic banks (Mohammed, 2005). Loan to Deposit Ratio (LDR) is how far the bank's ability to repay the withdrawal of funds by depositors by controlling loans as a source of liquidity. The higher this ratio, gives indication of the lack of bank liquidity. This is because the amount of funds required to finance the credit is grow (Dendawijaya, 2009). The amount of LDR follows the development of Indonesia’s economic condition. Based on Bank Indonesia Regulation (PBI) No. 15/7 / PBI / 2013 on Statutory Reserves of Commercial Banks in Bank Indonesia in Rupiah and Foreign Exchange, that the bank is considered healthy if the amount of the Loan to Deposit Ratio (LDR) to the lower limit of the loan to deposit ratio (LDR) target is 78\% and the upper limit of the Loan to Deposit Ratio (LDR) target is $92 \%$ from the date of December 2, 2013.

Biaya Operasional Pendapatan Operasional (BOPO) is used to measure the efficiency of the bank's ability to conduct its operations. The higher this ratio, the greater the bank's inefficient operating costs (Dendawijaya, 2009). 
Table. 4

Criteria of Biaya Operasional Pendapatan Operasional (BOPO)

Level Assessment

\begin{tabular}{ccc}
\hline Level & Criteria & Information \\
\hline Level 1 & REO $\leq 83 \%$ & Very high \\
Level 2 & $83 \%<$ REO $\leq 85 \%$ & High \\
Level 3 & $85 \%<$ REO $\leq 87 \%$ & Less high \\
Level 4 & $87 \%<$ REO $\leq 89 \%$ & Low \\
Level 5 & REO $>89 \%$ & Les low \\
\hline
\end{tabular}

Source: Bank Indonesia Circular Letter No. 9/24 / DPbS 2007

In a study conducted by Adi Stiawan (2009) examined the effect of the Capital Adequacy Ratio ( CAR ) of the return on assets (ROA). Research results showed a significant influence of the Capital Adequacy Ratio (CAR) of the return on assets (ROA) . However, these studies contradict the research Asma' Rashidah Idris, Fadli Fizari Abu Hassan Asari, Noor Asilah Abdullah Taufik, Nor Jana Salim, Rajmi Mustaffa and Kamaruzaman Jusoff (2011) and Muh. Sabir M, Muhammad Ali, and Abd. Hamid Habbe (2012). The results showed that the Capital Adequacy Ratio (CAR) did not significantly affect the return on assets (ROA).

In a study conducted by Adi Stiawan (2009) and Vishnu Aluisius N. (2011) related to the effect of non-performing financing (NPF) on Return on Assets (ROA) shows the result that the non-performing financing (NPF) significantly affect the return on assets ( ROA ). Aulia Fuad Rahman and Rochmanika Rida (2011) in his research stating that Non Performing Financing (NPF) positive effect on return on assets (ROA). However, research conducted both at odds with research Muh Sabir, Muhammad Ali , and Abd Hamid Habbe (2012) which showed that the nonperforming financing (NPF) no significant effect on return on assets (ROA).

Adi Stiawan (2009) conducted a study on the effect of Financing to Deposit Ratio (FDR) of the return on assets (ROA). The result of research indicated that the Financing to Deposit Ratio (FDR) significantly affect the return on assets (ROA). In the study Muh Sabir, Muhammad Ali, and Abd Hamid Habbe (2012) showed that the Financing to Deposit Ratio (FDR) positive and significant impact on the return on assets (ROA). The study contradicts the Suryani study (2011) that the Financing to Deposit Ratio (FDR) no significant effect on return on assets (ROA).

Operating Costs Operating Income (BOPO) studied Adi Stiawan (2009) and Aluisius Wishnu N. (2011) showed that the Operating Costs Operating Income (BOPO) significantly affect the return on assets (ROA). The Research Muh Sabir, Muhammad Ali, and Abd Hamid Habbe (2012), shows that the Operating Costs Operating Income (BOPO) significant negative effect on return on assets (ROA). 


\section{Methods}

The population in this research is Islamic Banks (IB). Sampling technique in this research is nonprobability Sampling is a sampling technique that does not give the opportunity / same opportunity for each element or member of the population to be elected as members of the sample (Sugiyono, 2011). Purposive Sampling Method is sampling technique with particular consideration (Sugiyono, 2011). Criteria for Islamic Banks are sampled Islamic Banks operating in the period 2005-2012 and Islamic Banks which presents data Quarterly Financial Report for the period 20052012. Based on these criteria, the sample used in this study is Bank of Muamalat Indonesia and Bank of Mega Syariah.

The data used in this research is secondary data from the Quarterly Financial Report of Financial Ratios Table issued and published on the Web site by Bank Muamalat Indonesia and Bank Syariah Mega period 2005 to 2012. The data and information obtained through the official website of Bank Indonesia. Method of analysis used in this research is the method of Multiple Linear Regression Analysis.

\section{Discussion}

Based on the result, it can be seen that the Return On Asset (ROA) has an average value of $2.39 \%$. Thus, ROA of Islamic banks have to fulfill the standards of Bank Indonesia, which means Islamic banks successfully manage its financial performance in increasing revenue and reducing costs. The average value of the Capital Adequacy Ratio (CAR) is $13.07 \%$. Thus statistically, CAR of Islamic banks are significantly higher than the provisions of Bank Indonesia, which means Islamic banks able to finance the operations of the bank to absorb losses on assets decline. Financing to Deposit Ratio (FDR) has an average of $84.48 \%$. So FDR of Islamic banks have to fulfill the standards of Bank Indonesia, which means the distribution of funding is greater than the funds deposited, because the main function of the bank is as intermediation (intermediary) between the parties with the excess funds with underfunded. Biaya Operasional Pendapatan Operasional (BOPO) reached an average of $83.38 \%$. So $B O P O$ ratio of Islamic banks comes into the second rank $(83 \%<\mathrm{REO} \leq 85 \%)$, which indicates that the efficiency of operational activities of Islamic banks are already good.

Based on the results of the amount of correlation between the independent variables, it appears that only the Operating Expenses Operating Income (BOPO) which has a quite high correlation with the variable Financing to Deposit Ratio (FDR) with a correlation of $58.7 \%$. Therefore, this correlation is still below $95 \%$, it can be said did not occur serious multicoloniarity. Multicoloniarity test results with see the value of tolerance and VIF. Results of tolerance calculation showed that were 
no independent variables have a tolerance value of less than 0.10 , which means there is no correlation between the independent variable whose value is more than $95 \%$. The result of the calculation Variance Inflation Factor (VIF) also showed the same thing that no one independent variable that has a value of more than 10 . So VIF can be concluded that there is no multicoloniarity in the regression model.

To determine the presence of autocorrelation in a regression model, then tested against the value of the Durbin-Watson (DW) test. The result show that the generate value Durbin-Watson (DW) 0,929. While in the table of DurbinWatson (DW) the number of samples $(\mathrm{n})=64$ and the number of independent variables $(\mathrm{k})=4$ and a significance level of 0.05 obtained values $(\mathrm{dl})=1.46$ and $(\mathrm{du})=1.73$. Therefore the calculation can be concluded that there is a positive autocorrelation. Because the regression model contained autocorrelation problem, it is necessary to measure improvement. Improvements are considered appropriate is to use a technique Generalized Least Square (GLS) that is a method to get rid of the first order autocorrelation (first order autocorrelation) in a regression equation estimation. Then the method used to estimate the value of $p$ is the method CochraneOreutt is a technique replicates of two stages: the first stage is to run a regression to the initial equation then predicted coefficient $\mathrm{p}$ by running regression equation based on the suspected residue containing autocorrelation. Then, the second stage is using an estimate of the autocorrelation coefficient, where $\mathrm{p}$ is used to estimate the Generalized Least Square equation by substituting estimation p. After performing OLS regression techniques, we then look for the first iteration $\mathrm{p}$ value estimate for estimating the generalized difference equation in the equation.

The test results of Durbin-Watson (DW) after repair autocorrelation as follows. In the previous regression equation, the value of the Durbin-Watson (DW) of 0,929 and consist a positive autocorrelation, while the regression equation after repair generate of Durbin-Watson value (DW) of 1.920 which means it did not happen autocorrelation.

From the result shows that dots dispersed and scattered above and below the number 0 on the $\mathrm{Y}$ axis, there is no specific pattern that is irregular or no clear pattern. Therefore, it can be concluded that there is no heteroscedasticity in this regression models.

Testing the normality of the data to statistical analysis performed using Kolmogorov-Smirnov (KS). In multivariate normality tests performed on residual value. The data indicated a normal distribution with significant value above 0.05 or 5\% (Ghozali, 2011). The value of the Kolmogorov-Smirnov (KS) are 1.056 and 0.215 significance. It can be concluded that the distribution pattern of the residuals are normally distributed, so the regression model fulfill the normality test. 
The coefficient of determination (R2) was essentially measures how far the ability of the model to explain variations in the dependent variable (Ghozali, 2011). The coefficient of determination can be seen as follows. The amount of Adjusted $\mathrm{R}$ Square (R2) is 0.657 . The results of this statistical the calculation shows the variation of the Capital Adequacy Ratio (CAR), Non Performing Financing (NPF), Financing to Deposit Ratio (FDR) and Biaya Operasional Pendapatan Operasional (BOPO) can explain the variation of $65.7 \%$ Return On Asset (ROA). While the remaining $34.3 \%$ is explained by other factors beyond the regression model are analyzed.

The statistical test $\mathrm{F}$ basically indicates whether all the independent variables included in the model have jointly influence on the dependent variable. Based on the results of SPSS output simultaneously the influence of independent variables on the dependent variable can be seen as follow. On the result of statistical test F, obtained calculated $\mathrm{F}$ value is 30.641 and 0.000 significance level. Because the level of significance less than 0.05 and the result $\mathrm{F}$ count is greater than the $\mathrm{F}$ table (30.641> 2.53), it can be concluded that the Capital Adequacy Ratio (CAR), Non Performing Financing (NPF), Financing to Deposit Ratio (FDR) and Biaya Operasional Pendapatan Operasional (BOPO) simultaneously significant effect on Return On Asset (ROA).

$T$ statistical test indicates how far the influence of the independent variables individually in explaining variation dependent variable. The results of test calculations obtained partial t Variable Capital Adequacy Ratio (CAR) of -0.478 with a significance value of $(0.634>0.05)$. It can be concluded that the Capital Adequacy Ratio (CAR) partially negative but insignificant effect on the Return On Asset (ROA). This means that the higher the level of Capital Adequacy Ratio (CAR) of a bank did not a barometer of the success of the bank's management in obtaining high profits because capital owned banks have not used optimally in the distribution of funding which the CAR only serves as a backup capital which resulted in the bank's capital funds to settle unproductive or idle (idle funds).

The results of test calculations obtained partial t Variable Non-Performing Financing (NPF) of -0.189 with a significance value of $(0.851>0.05)$. It can be concluded that the Non-Performing Financing (NPF) partially negative but insignificant effect on the Return on Asset (ROA). The results of this research indicate the possibility of resulting value Penyisihan Penghapusan Aktiva Produktif (PPAP) can still cover the financing problems. Bank profits can still be increased by the high of Non Performing Financing (NPF), because banks are still able to obtain, not only a source of income from the finance portfolio, but also from other income sources also provide a relatively high influence on the rate of Return on Asset.

The results of test calculations obtained partial t Variable Financing to Deposit 
Ratio (FDR) of -1.411 with a significance value of $(0.164>0.05)$. It can be concluded that the Financing to Deposit Ratio (FDR) partially negative but insignificant effect on the Return On Asset (ROA). The results of this research showed the higher this ratio, the greater the illiquid banks. The more illiquid bank greater the liquidity risk borne by the bank, so contained the risk of unavailability of liquid assets to fulfill obligations to customers. Trending negative liquidity risk due to the results of a given financing to be borne by the bank increase, so the Return On Asset (ROA) decreased. The level of bank's ability to withdraw funds from low customer and the bank did not have a reserve fund to restore customer funds savers.

The results of test calculations obtained partial t Variable Operating Expenses Operating Income (BOPO) of -10.207 with significance value of $(0.000>0.05)$. It can be concluded that the Biaya Operasional Pendapatan Operasional (BOPO) partially significant negative effect on Return On Asset (ROA). The results of this research indicate that if the operations are conducted efficiently generated revenue the bank will increase or more efficient performance of the operations of a bank, the profit earned by the bank will be even greater.

\section{Conclusion}

Besides the explanation above it can be concluded that through the F statistic test results simultaneously from each of the dependent variables with independent showed that the Capital Adequacy Ratio (CAR), Non Performing Financing (NPF), Financing To Deposit Ratio (FDR) and Biaya Operasional Pendapatan Operasional (BOPO) significantly affected on Return On Asset (ROA). While the statistical t test results partially from each of the dependent variable showed that the Capital Adequacy Ratio (CAR) did not significantly influence the return on assets (ROA). The results are consistent with previous studies conducted by Asma 'Rashidah Idris et al (2011) and Muh. Sabir M et al (2012) that the variable Non Performing Financing (NPF) has no significant effect on Return on Assets (ROA). These results are also consistent with previous studies conducted by Muh. Sabir M et al (2012). As for the variable Financing To Deposit Ratio (FDR) did not significantly influence the Return On Assets (ROA). The result of this study is also in line with previous research conducted by Syriac (2011). And for variable Operating Costs Operating Income (ROA) significantly affects the return on assets (ROA). And the results are consistent with previous studies conducted by Adi Stiawan (2009) and Aluisius Vishnu, N. (2011)

Based on the conclusion above, we can suggest that: it is important to make an optimal asset management through financing or business expansion. So, there are no idle funds that could result settles unproductive asset. The application of the 
precautionary principle in the management of the financing conducted to minimize the risk of financing so as to improve profitability and can manage funds raised from the public and then redistributed in the form of financing, allocation of funds held should be distributed in a variety of forms of investment that will be able to increase the income of the bank, either in the form of bonuses and profit-sharing, which means sharia banks profit will increase and control the income and expenses of special concern to always be at a level of efficiency that can generate maximum profit, so that the performance achieved will always increase.

\section{References}

Bank Indonesia. 2007. Peraturan Bank Indonesia (PBI) No. 9/1/PBI/2007 tentang Sistem Penilaian Tingkat Kesehatan Bank Umum Berdasarkan Prinsip Syariah dalam http://www.bi.go.id, diunduh pada tanggal 6 September 2014

Bank Indonesia. 2007. Surat Edaran Bank Indonesia No.9/24/DPbS tahun 2007 perihal Sistem Penilaian Tingkat Kesehatan Bank Umum Berdasarkan Prinsip Syariah dalam http://www.bi.go.id, diunduh pada tanggal 8 September 2014

Bank Indonesia. 2012. Peraturan Bank Indonesia (PBI) No. 14/14/PBI/2012 tentang Transparansi dan Publikasi Laporan Bank dalam http://www.bi.go.id, diunduh pada tanggal 8 September 2014

Bank Indonesia. 2013. Peraturan Bank Indonesia (PBI) No. 15/7/PBI/2013 tentang Giro Wajib Minimum Bank Umum Pada Bank Indonesia Dalam Rupiah dan Valuta Asing dalam http://www.bi.go.id, diunduh pada tanggal 30 Desember 2014.

Dendawijaya, L. 2009, Manajemen Perbankan. Bogor: Ghalia Indonesia.

Ghozali, I. 2011. Aplikasi Analisis Multivariate dengan Program IBM SPSS 19. Semarang: Badan Penerbit Universitas Diponegoro.

Idris, A.R, et.al. 2011. Determinant of Islamic Banking Institutions' Profitability in Malaysia. World Applied Sciences Journal 12, pp 88-100.

Kasmir. 2012. Manajemen Perbankan. Jakarta: Raja Grafindo Persada.

Kuncoro, M. \& Suhardjono. 2011. Manajemen Perbankan: Teori dan Perbankan. Yogyakarta: BPFE Yogyakarta.

Muhammad. 2005. Manajemen Bank Syariah. Yogyakarta: Unit Penerbit dan Percetakan AMP YKPN.

Muhammad, R. 2008. Akuntansi Keuangan Syariah, Konsep dan Implementasi PSAK Syariah. Yogyakarta: P3EI Press.

Nugroho, A.W. 2011. Analisis Pengaruh FDR, NPF, BOPO, KAP dan PLO terhadap ROA: Studi pada Bank Syariah di Indonesia periode tahun 2006-2010. (Thesis 
Unpublished). Semarang: Universitas Diponegoro.

Riyadi, S. 2006. Banking Asset \& Liability Management. Jakarta: Lembaga Penerbit Fakultas Ekonomi Universitas Indonesia.

Sabir, Muh. et.al. 2012. Pengaruh Rasio Kesehatan Bank terhadap Kinerja Keuangan Bank Umum Syariah dan Bank Konvensional di Indonesia. Jurnal Analisis, Volume 1, Nomor 1, Juni 2012, pp. 79-86.

Santoso, T.B. \& S. Triandaru. 2006. Bank dan Lembaga Keuangan Lain. Jakarta: Salemba Empat.

Stiawan, A. 2008. Analisis Pengaruh Faktor Makroekonomi, Pangsa Pasar dan Karakteristik Bank terhadap Profitabilitas Bank Syariah: Studi pada Bank Syariah Periode 2005-2008. (Thesis Unpublished). Semarang: Universitas Diponegoro.

Sugiyono. 2011. Statistika untuk Penelitian. Bandung: Alfabeta.

Suryani. 2011. Analisis Pengaruh Financing to Deposit Ratio (FDR) terhadap Profitabilitas Perbankan Syariah di Indonesia. Jurnal Walisongo, Volume 19, Nomor 1, pp. 35-50. 